\title{
Ectoine as a promising protective agent in humans and animals
}

\author{
Adam Bownik ${ }^{1}$ and Zofia Stępniewska ${ }^{2}$ \\ Department of Biological Basis of Animal Production, Faculty of Biology, Animal Sciences and Bioeconomy, \\ University of Life Sciences in Lublin ${ }^{l}$, Department of Biochemistry and Environmental Chemistry, Faculty of \\ Biotechnology and Environmental Sciences, John Paul II Catholic University of Lublin², Lublin, Poland
}

[Received in May 2016; CrossChecked in May 2016; Accepted in November 2016]

\begin{abstract}
Ectoine is a compatible water molecule-binding solute (osmoprotectant) produced by several bacterial species in response to osmotic stress and unfavourable environmental conditions. This amino acid derivative can accumulate inside cells at high concentrations without interfering with natural processes and can protect the cell against radiation or osmotic stress. This brief review presents the current state of knowledge about the effects of ectoine on animals and focuses on its practical use for enzyme stabilisation, human skin protection, anti-inflammatory treatment, inhibitory effects in neurodegenerative diseases, and other therapeutic potential in human or veterinary medicine.
\end{abstract}

KEY WORDS: cell protection; compatible solute; macromolecular stability; osmoprotectant

Various organisms have developed different mechanisms to protect themselves against stress caused by environmental factors such as drought or extreme temperatures. Bacteria, especially those living in extreme environments, have the ability to produce compounds of small molecular weight known as compatible solutes or osmoprotectants, which do not interfere with cellular processes. They can accumulate to high concentrations and prevent cell dehydration (1). According to the structure, compatible solutes belong to the following groups: sugars (sucrose, trehalose), polyols (sorbitol, glycerol, mannitol, mannosyl-glyceramide, mannosyl-glycerol), $N$-acetylated diamino acids ( $N$-acetylglutaminylglutamine amide), betaines (betaine, glycine, and deritatives), and amino acids and derivatives (proline, glutamate, glutamine, alanine, ectoine, and hydroxyectoine).

These substances strongly bind water molecules and stabilise macromolecules. Although their mechanism of action is not entirely known, there are several hypotheses explaining biophysical principles by which they act. The most widely accepted hypothesis is the "preferential exclusion model", according to which osmoprotectants do not interact directly with the macromolecule in an aqueous solution but are repelled to the bulk region, increasing macromolecule's hydration and thereby preventing its denaturation (2-4).

Ectoine (1,4,5,6-tetrahydro-2-methyl-4-pyrimidine carboxylic acid; for structure see Figure 1a) is a water-

Correspondence to: Adam Bownik, Department of Biological Basis of Animal Production, Faculty of Biology, Animal Sciences and Bioeconomy, University of Life Sciences in Lublin, Akademicka 13 Str., 20-950 Lublin, Poland; E-mail: adambownik@wp.pl binding zwitterionic amino acid derivative (142,156 Da), first isolated from Ectothiorhodospira halochloris (5). It is also produced and accumulated by other, mainly aerobic, chemoheterotrophic and halophilic bacteria, such as alphaand gammaproteobacteria and Actinobacteridae, in which it stabilises cell membranes, enzymes, and nucleic acids at extreme temperatures or higher salt concentrations (6). Ectoine synthesis from its precursor, L-aspartate- $\beta$ semialdehyde is catalysed by ectoine $\mathrm{ABC}$ enzymes, including diaminobutyric acid (DABA) acetyltransferase (ectA), DABA aminotransferase (ectB), and ectoine synthase (ectC) (7). Genes encoding these enzymes are organised in either ectABC or ectABC-ask operons (8).

A number of biophysical studies show that ectoine binds water molecules even better than some other osmoprotectants such as glycerol $(9,10)$ and that it is well tolerated by humans, animals, and various cell cultures. In fact, ectoine retains strong hydration properties even at high $\mathrm{NaCl}$ concentrations (11).

The aim of this brief review is to present the current state of knowledge about the effects of ectoine on animals and discuss its practical use in enzyme stabilisation, human skin protection, anti-inflammatory treatment, prevention of neurodegenerative diseases, and other therapeutic potentials in human or veterinary medicine.

\section{Skin protection}

Ectoine has widely been used in cosmetic anti-ageing and moisturising creams to improve skin resistance to surfactants in skin cleansing solutions (12). It is an effective long-term moisturiser that prevents dehydration of the epidermis, even superior to the well-known membrane 
<smiles>CC1=N[C@@H](C(=O)O)CCN1</smiles>
b)<smiles>CC1=N[C@H](C(=O)O)[C@H](O)CN1</smiles>

Figure 1 Structural variants: ectoine (a) and hydroxyectoine (b)

stabiliser phosphatidylcholine. Some authors suggest that at relatively low concentrations (up to $500 \mu \mathrm{mol} \mathrm{L}^{-1}$ ) it can also be used as a whitening agent because of its inhibitory effect on melanin synthesis in B16-F0 and A2058 melanoma cell lines and on mushroom and cellular tyrosinase activities (13). Ectoine also alleviates skin inflammation and is currently recommended for the treatment of moderate atopic dermatitis (14).

In addition, ectoine strongly absorbs ultraviolet (UV) radiation and protects DNA from breaking down in various cell types $(15 ; 16)$. Grether-Beck et al. (17) reported that ectoine reduced UV-A-induced ceramide signalling response in human keratinocytes, while Buenger et al. (16) reported protective effects against UV radiation in immunocytes and Langerhans cells.

\section{Stabilising enzyme activity}

A number of studies have indicated that ectoine increases the stability of enzymes maintaining hydration and thereby reducing protein susceptibility to denaturation. Interestingly, this amino acid derivative does not interact directly with protein surfaces but rather it forms a molecular net holding water molecules close to the macromolecule $(10,18,19)$. Moreover, Roychoudhury et al. (20) have shown that ectoine, like other compatible solutes, strengthens intramolecular interactions essential for protein stability. Ectoine reduces denaturation of enzymes induced by a rapid change of temperature. It prolongs the activity of lactate dehydrogenase (LDH) and phosphofructokinase, enzymes that are normally sensitive to freeze-thawing, heating, and freeze-drying (21). It also increases the stability of phytase, ribonuclease-A, and polymerase of the doublestranded DNA at elevated temperature $(22,23)$.

Tenne et al. (24) found that ectoine derivative hydroxyectoine (for structure see Figure 1b) is even superior to ectoine in protecting against elevated temperatures.

Ectoine has also been reported to protect macromolecules against proteolytic agents. For example, zymogens chymotrypsinogen and trypsinogen were resistant to proteolysis by enteropeptidases (25). Another study showed that antibodies treated with ectoine were less susceptible to proteolytic degradation by pepsin (26).

In addition, ectoine can inhibit HIV replication (23) and can also stabilise retroviral vectors for gene therapy, which

may be a useful property, because these vectors usually lose their infectivity during long-term storage and transport (27).

\section{Cell protection}

Various environmental stressors such as heat or toxic chemicals may impair the cell membrane function and result in cell dehydration and denaturation. Harishchandra et al. (28) propose that ectoine increases cell membrane fluidity to cope with extreme conditions such as high temperature or osmotic pressure. A recent biophysical study by Zacchai et al. (10) showed that ectoine is excluded from the hydration layer at the membrane surface and does not affect membrane molecular dynamics. Moreover, improved hydration of the cell surface thanks to ectoine increases intermolecular spacing and boosts the mobility of the lipid head groups in the cell membrane (Figure 2) (29).

Different types of cells subjected to high temperature tend to produce chaperone proteins such as heat shock proteins (Hsp), which repair misfolded peptides. Ectoine seems to affect their synthesis and is speculated to act as a chaperone molecule itself (30). Buommino et al. (31) reported that heat-stressed keratinocytes incubated with ectoine had higher levels of Hsp70 and inhibited the production of pro-inflammatory signals.

Some studies indicate that ectoine shows promising properties against the detrimental effects of some toxic compounds. In a study by Graf et al. (12) ectoine-treated human erythrocytes were more resistant to membranedamaging sodium dodecyl sulphate detergent than untreated cells. Our recent study (32) has shown that ectoine has a potential to block pore-forming toxins, as the isolated bovine erythrocytes treated with ectoine turned out to be less sensitive to staphylococcal alpha-haemolysin. Interestingly, the toxin monomers preincubated with ectoine were less cytotoxic than those added to the cell suspension simultaneously with ectoine, which suggests that ectoine blocks the unfolding of the toxin monomers and thus prevents the formation of transmembrane pores in the cell membrane. These findings suggest that ectoine may be useful in protecting erythrocytes from staphylococcal haemolysins. Little is known, however, about ectoine protective effects against toxins produced by other bacterial species, mycotoxins, and toxic proteins found in animal venom. Future research should answer whether the osmoprotectant could be an effective antidote.

\section{Alleviation of inflammatory reaction}

Ectoine effectively alleviates inflammation, such as the experimentally induced colitis in rats (33) or nanoparticleinduced neutrophilic lung inflammation (34). It can also mitigate inflammatory reactions in the lung epithelial cells after inhalation of carbonaceous nanoparticles in mice. However, this effect was not observed when lung inflammation was induced by bacterial lipopolysaccharide (35). Peuschel et al. (36) reported that inhalational exposure 

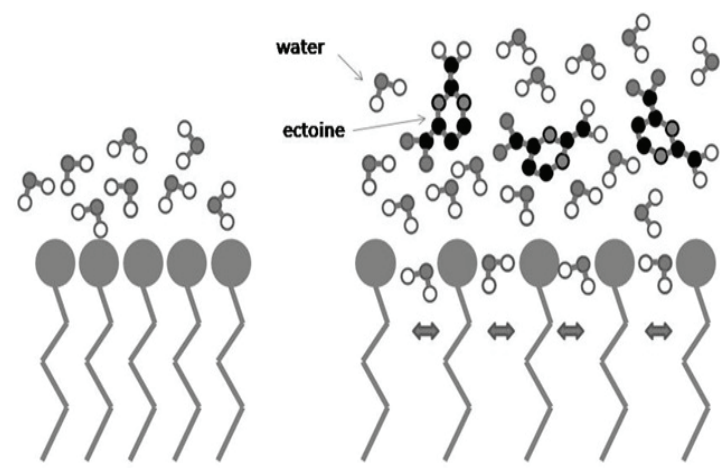

a)

b)

Figure 2 Influence of water molecules alone (a) and aqueous solution of ectoine (b) on lipid monolayer. Ectoine increases the distance between lipid molecules and improves membrane fluidity.

to carbon nanoparticles in mice resulted in the accumulation of ceramides in lipid rafts of cell membranes, activation of epidermal growth factor receptor (EGFR), and lung inflammation. Animals additionally treated with ectoine, however, showed milder allergic reactions because ectoine seems to have inhibited ceramide-mediated EGFR phosphorylation. Another study showed that ectoine and hydroxyectoine enhance lung surfactants, which suggests their potential use as supporting factors in inhalation therapy (37).

Ectoine was also found to protect ileal mucosa against ischaemia and reperfusion injury, which are common complications after the small bowel transplantation (38, 39). Alleviating the inflammatory reaction is related to the improvement of intestinal barrier and reduction of cytokine production (33).

Nasal spray and air drops containing ectoine are the new approaches to treating allergic rhinitis, rhinoconjunctivitis, and dry eye syndrome (29). Some studies showed that products containing ectoine may be a better alternative to other products, as they reduce ocular and nasal symptoms with no side effects (40-42). Promising effects such as reduction of nasal airway obstruction and crust formation were also observed in patients with rhinitis sicca anterior treated with nasal spray containing ectoine alone or in combination with dexpanthenol (43). Moreover, a recent study has shown that a mouth and throat spray containing ectoine can be very effective in the treatment of acute pharyngitis and laryngitis (44).

\section{Cryoprotection}

Compatible solutes such as ectoine and hydroxyectoine are effective agents in cryopreservation. Bissoyi and Pramanik (45) reported it to be an efficient additive in cryoprotective media for mononuclear cells isolated from human umbilical cord blood. Their $10 \%$ foetal bovine serum medium containing a combination of hydroxyl ethyl starch, ectoine, and co-enzyme Q10 yielded the highest, $93 \%$ viability of mononuclear cells. Sun et al. (46) reported that both ectoine and hydroxyectoine protected human endothelial cell line HPMEC-ST1.6R or mesenchymal stem cells and suggested that they may be used in cryobiology as an alternative to the toxic dimethyl sulphoxide (DMSO). One study on rats (47) showed that adding hydroxyectoine to the histidine-tryptophan-ketoglutarate solution reduces the cold ischaemic preservation injury of livers donated after cardiac death and used for transplantation. Ectoine was also successfully used as a cryoprotectant of human erythrocytes, as it prevented slow-freezing cell damage (48).

\section{Protection against neurodegenerative diseases}

Some pathological processes like amyloid formation and aggregation induce neurodegenerative diseases. Ectoine was found to prevent amyloid formation and delay the onset and progression of Alzheimer's disease (49). Other studies have shown that this amino acid derivative inhibits insulin amyloid formation and interacts with prion aggregation responsible for transmissible spongiform encephalopathies (50-52).

\section{Protection of invertebrates against environmental stressors}

Little is known about how ectoine acts in invertebrates. In our earlier studies (53-55) ectoine showed protective effects in Daphnia magna subjected to high temperature by inhibiting heat shock protein Hsp70, catalase activity, and NO radicals. Moreover, ectoine-treated Daphnia magna were more resistant to toxic disinfectants formaldehyde and hydrogen peroxide than untreated controls, as manifested through significantly lower mortality rates, better swimming activity, and better physiological parameters such as heart rate and thoracic limb activity (56). In practice, it could be used as a stabilising agent during the transport of some edible species sensitive to different forms of stress.

\section{CONCLUSION}

As ectoine is a potent protective agent against different forms of stress without toxic side effects, its current use in biotechnology, cosmetics, and medicine, leaves a lot of room for many innovative applications. However, since the reviewed literature covers a wide range of studies of different complexity, from isolated macromolecules and cell cultures to various animal species, the protective effects of ectoine observed in simple systems may fail in more complex ones. Moreover, ectoine inactivates some molecules; therefore its use may be limited due to possible interactions with other pharmaceuticals.

\section{REFERENCES}

1. Kempf B, Bremer E. Uptake and synthesis of compatible solutes as microbial stress responses to high-osmolality 
environments. Arch Microbiol 1998;170:319-30. PMID: 9818351

2. Arakawa T, Timasheff SN. The stabilization of proteins by osmolytes, Biophys J 1985;47:411-4. doi: 10.1016/S00063495(85)83932-1

3. Moelbert S, Normand B, de Los Rios P. Kosmotropes and chaotropes: modelling preferential exclusion, binding and aggregate stability. Biophys Chem 2004;112:45-57. doi: 10.1016/j.bpc.2004.06.012

4. Yu I, Jindo Y, Nagaoka M. Microscopic understanding of preferential exclusion of compatible solute ectoine: direct interaction and hydration alteration. J Phys Chem 2007;111:10231-8. doi: 10.1021/jp068367z

5. Galinski EA, Pfeiffer H-P, Trupper HG. 1,4,5,6-Tetrahydro2-methyl-4-pyrimidinecarboxylic acid. A novel cyclic amino acid from halophilic phototrophic bacteria of the genus Ectothiorhodospira. Eur J Biochem 1985;149:135-9. doi: 10.1111/j.1432-1033.1985.tb08903.x

6. Smiatek J, Harishchandra RK, Rubner O, Galla H-J, Heuer A. Properties of compatible solutes in aqueous solution. Biophys Chem 2012;160:62-8. doi: 10.1016/j. bpc.2011.09.007

7. Widderich N, Czech L, Elling FJ, Könneke M, Stöveken N, Pittelkow M, Riclea R, Dickschat JS, Heider J, Bremer E, Strangers in the archaeal world: osmostress-responsive biosynthesis of ectoine and hydroxyectoine by the marine thaumarchaeon Nitrosopumilus maritimus. Environ Microbiol. 2016; 18:1227-48. doi: 10.1111/1462-2920.13156

8. Reshetnikov AS, Khmelenina VN, Mustakhimov II, Trotsenko YA. Genes and enzymes of ectoine biosynthesis in halotolerant methanotrophs. Methods Enzymol. 2011; 495:15-30. doi: 10.1016/B978-0-12-386905-0.00002-4.

9. Heinrich U, Garbe B, Tronnier H. In vivo assessment of Ectoin: a randomized, vehicle-controlled clinical trial. Skin Pharmacol Appl Skin Physiol 2007;20:211-8. doi: 10.1159/000103204

10. Zaccai G, Bagyan I., Combet J, Cuello GJ, Demé B, Fichou Y, Gallat F-X, Josa V.M.G, von Gronau S, Haertlein M, Martel, A, Moulin M, Neumann M, Weik M, Oesterheltb D. Neutrons describe ectoine effects on water H-bonding and hydration around a soluble protein and a cell membrane. Sci Rep 2016;6:31343.

11. Eiberweiser A, Nazet A, Kruchinin SE, Fedotova M.V, Buchner R. Hydration and ion binding of the osmolyte ectoine. J Phys Chem B 2015;119:15203-11.

12. Graf R, Anzali S, Buenger J, Pfluecker F, Driller H. The multifunctional role of ectoine as a natural cell protectant Clin Dermatol 2008;26:326-33. doi: 10.1016/j. clindermatol.2008.01.002.

13. Yao C-L, Lin Y-M, Mohamed M.S, J-H Chen Inhibitory effect of ectoine on melanogenesis in B16-F0 and A2058 melanoma cell lines. Biochem Engineer J 2013;78:163-9

14. Marini A, Reinelt K, Krutmann J, Bilstein A. Ectoinecontaining cream in the treatment of mild to moderate atopic dermatitis: a randomised, comparator-controlled, intraindividual double-blind, multi-center trial. Skin Pharmacol Physiol 2014;27:57-65. doi: 10.1159/000351381.

15. Botta C, Di Giorgio C, Sabatier AS, De Meo M. Genotoxicity of visible light $(400-800 \mathrm{~nm})$ and photoprotection assessment of ectoin, L-ergothioneine and mannitol and four sunscreens.
J PhotochemPhotobiol 2008;91:24-34. doi: 10.1016/j. jphotobiol.2008.01.008.

16. Buenger J, Driller H. Ectoin: An effective natural substance to prevent UVA-induced premature photoaging. Skin Pharmacol Physiol 2004;17:232-7. doi: 10.1159/000080216

17. Grether-Beck S, Timmer A, Felsner I, Brenden H, Brammertz D, Krutmann J. Ultraviolet A-induced signaling involves a ceramide mediated autocrine loop leading to ceramide de novo synthesis. J Investig Dermatol 2005;125:545-53. doi: 10.1111/j.0022-202X.2005.23782.x

18. Foord RL, Leatherbarrow RJ. Effect of osmolytes on the exchange rates of backbone amide protons in proteins. Biochemistry 1998;37:2969-78. doi: 10.1021/bi9712798.

19. Plaza del Pino IM, Sanchez-Ruiz JM. An osmolyte effect on the heat capacity change for protein folding. Biochemistry 1995;34:8621-30. doi: 10.1021/bi00027a011

20. Roychoudhry A, Bieker A, Häussinger D, Oesterhelt F. Membrane protein stability depends on the concentration of compatible solutes - a single molecule force spectroscopic study. Biol Chem 2013;394:1465-74. doi: 10.1515/hsz-2013-0173

21. Lippert K, Galinski EA. Enzyme stabilization be ectoine-type compatible solutes: protection against heating, freezing and drying. Appl Microbiol Biotechnol 1992;37:61-5. doi: 10.1007/BF00174204

22. Zhang L, Wang Y, Zhang C, Wang Y, Zhu D, Wang C, Nagata S. Supplementation effect of ectoine on thermostability of phytase. J Biosci Bioeng 2006;102:560-3. doi: 10.1263/ jbb. 102.560

23. Lapidot A, Ben-Asher E, Eisenstein M. Tetrahydropyrimidine derivatives inhibit binding of a Tat-like, arginine-containing peptide, to HIV TAR RNA in vitro. FEBS Lett 1995;367:338. doi: 10.1016/0014-5793(95)00514-A

24. Tanne C, Golovina EA, Hoekstra FA, Meffert A, Galinski E. Glass-forming property of hydroxyectoine is the cause of its superior function as a desiccation protectant. Front Microbiol 2014;5:150. doi: 10.3389/fmicb.2014.00150

25. Kolp S, Pietsch M, Galinski EA, Gütschow M. Compatible solutes as protectants for zymogens against proteolysis. Biochim Biophys Acta 2006;1764:1234-42. doi: 10.1016/j. bbapap.2006.04.015

26. Bersch S, Vangala M, Schwarz T, Kaufmann M. Protection of antibodies against proteolytic degradation by compatible solutes. Poster Abstract, 2000 [displayed 3 November 2016]. Available at http://www.ejbiotechnology.info/feedback/ proceedings $/ 04 /$ poster $/ \mathrm{p} 26 . \mathrm{html}$

27. Cruz PE, Silva AC, Roldão A, Carmo M, Carrondo MJT, Alves PM. Screening of novel excipients for improving the stability of retroviral and adenoviral vectors. Biotechnol Prog 2006;22:568-76. doi: 10.1021/bp050294y

28. Harishchandra RK, Wulff S, Lentzen G, Neuhaus T, Galla H-J. The effect of compatible solute ectoines on the structural organization of lipid monolayer and bilayer membranes. Biophys Chem 2010;150:37-46. doi: 10.1016/j.bpc.2010.02.007

29. Dwivedi M, Brinkkötter M, Harishchandra RK, Galla HJ. Biophysical investigations of the structure and function of the tear fluid lipid layers and the effect of ectoine. Part B: artificial lipid films. Biochim Biophys Acta 2014;1838:271627. doi: 10.1016/j.bbamem.2014.05.007

30. Becker J, Schäfer R, Kohlstedt M, Harder BJ, Borchert NS, Stöveken N, Bremer E, Wittmann C. Systems metabolic engineering of Corynebacterium glutamicum for production 
of the chemical chaperone ectoine. Microb Cell Fact 2013;12:110. doi: 10.1186/1475-2859-12-110

31. Buommino E, Schiraldi C, Baroni A, Paoletti I, Lamberti M, De Rosa M, Tufano MA. Ectoine from halophilic microorganisms induces the expression of hsp 70 and hsp70B' in human keratinocytes modulating the proinflammatory response. Cell Stress Chaperon 2005;10:197-203. doi: 10.1379/CSC-101R.1

32. Bownik A, Stępniewska Z. Protective effects of bacterial osmoprotectant ectoine on bovine erythrocytes subjected to staphylococcal alpha-haemolysin. Toxicon 2015;99:130-5. doi: 10.1016/j.toxicon.2015.03.022

33. Abdel-Aziz H, Wadie W, Abdallah DM, Lentzen G, Khayyal MT. Novel effects of ectoine, a bacteria-derived natural tetrahydropyrimidine, in experimental colitis. Phytomedicine 2013;20:585-91. doi: 10.1016/j.phymed.2013.01.009

34. Sydlik U, Gallitz I, Albrecht C, Abel J, Krutmann J, Unfried $\mathrm{K}$. The compatible solute ectoine protects against nanoparticle-induced neutrophilic. Am J Respir Crit Care Med 2009;180:29-35.

35. Kroker M, Sydlik U, Autengruber A, Cavelius C, Weighardt $\mathrm{H}$, Kraegeloh A, Unfried K. Preventing carbon nanoparticleinduced lung inflammation reduces antigen-specific sensitization and subsequent allergic reactions in a mouse model. Part Fibre Toxicol 2015;12:20. doi: 10.1186/s12989015-0093-5

36. Peuschel H, Sydlik U, Grether-Beck S, Felsner I, Stöckmann D, Jakob S, Kroker M, Haendeler J, Gotić M, Bieschke C, Krutmann J, Unfried K. Carbon nanoparticles induce ceramide- and lipid raft-dependent signalling in lung epithelial cells: a target for a preventive strategy against environmentally-induced lung inflammation. Part Fibre Toxicol 2012;9:48. doi: 10.1186/1743-8977-9-48

37. Harishchandra RK, Sachan AK, Kerth A, Lentzen G, Neuhaus T, Galla HJ. Compatible solutes: Ectoine and hydroxyectoine improve functional nanostructures in artificial lung surfactants. Biochim Biophys Acta 2011;1808:2830-40. doi: 10.1016/j.bbamem.2011.08.022

38. Wei L, Wedeking A, Buttner R, Kalff JC, Tolba RH, van Echten-Deckert G. A natural tetrahydropyrimidine protects small bowel from cold ischemia and subsequent warm in vitro reperfusion injury. Pathobiology 2009;76:212-20. doi: $10.1159 / 000218338$

39. Pech T, Ohsawa I, Praktiknjo M, Overhaus M, Wehner S, von Websky M, Abu-Elmagd K, van Echten-Deckert G, Kalff JC, Schaefer N. A natural tetrahydropyrimidine, ectoine, ameliorates ischemia reperfusion injury after intestinal transplantation in rats. Pathobiology 2013;80:102-10. doi: $10.1159 / 000342792$

40. Werkhäuser N, Bilstein A, Sonnemann U. Treatment of allergic rhinitis with ectoine containing nasal spray and eye drops in comparison with azelastine containing nasal spray and eye drops or with cromoglycic acid containing nasal spray. J Allergy (Cairo) 2014, Article ID 176597. doi: $10.1155 / 2014 / 176597$

41. Sonnemann U, Scherner O, Werkhäuser N. Treatment of rhinitis sicca anterior with ectoine containing nasal spray. J Allergy (Cairo) 2014, Article ID 273219. doi: $10.1155 / 2014 / 273219$

42. Eichel A, Bilstein A, Werkhäuser N, Mösges R. Meta-analysis of the efficacy of ectoine nasal spray in patients with allergic rhinoconjunctivitis. J Allergy (Cairo) 2014. Article ID 292545. doi: $10.1155 / 2014 / 292545$

43. Sonnemann U, Möller M, Bilstein A. Non interventional open-label trial investigating the efficacy and safety of ectoine containing nasal spray in comparison with beclomethasone nasal spray in patients with allergic rhinitis. J Allergy (Cairo)2014,Article ID 297203. doi: 10.1155/2014/297203

44. Müller D, Lidermann T, Shah-Hosseini K, Scherner O, Knop M, Bilstein A, Mösges R. Efficacy and tolerability of an ectoine mouth and throat spray compared with those of saline lozenges in the treatment of acute pharyngitis and/or laryngitis: a prospective, controlled, observational clinical trial. Eur Arch Otorhinolaryngol 2016;273:2591-7. doi: 10.1007/s00405-016-4060-z

45. Bissoyi A, Pramanik K. Effects of non-toxic cryoprotective agents on the viability of cord blood derived MNCs. Cryo Lett 2014;34:453-65. PMID: 24448765

46. Sun H, Glasmacher B, Hofmann N. Compatible solutes improve cryopreservation of human endothelial cells. Cryo Lett 2012;33:485-93. PMID: 23250408

47. Kadaba Srinivasan P, Fet N, Bleilevens C, Afify M, Doorschodt B, Yagi S, van Echten-Deckert G, Tolba RH Hydroxyectoine ameliorates preservation injury in deceased after cardiac death donors in experimental liver grafts. Ann Transplant 2014;19:165-73.

48. ElAssal R, Guven S, Gurkan UA, Gozen I, Shafiee H, Dalbeyler S, Abdalla N, Thomas G, Fuld W, Illigens BM, Estanislau J, Khoory J, Kaufman R, Zylberberg C, Lindeman N, Wen Q, Ghiran I, Demirci U. Bio-inspired cryo-ink preserves red blood cell phenotype and function during nanoliter vitrification. Adv Mater 2014;26:5815-22. doi: 10.1002/adma.201400941

49. Kanapathipillai M, Lentzen G, Sierks M, Park CB. Ectoine and hydroxyectoine inhibit aggregation and neurotoxicity of Alzheimer's beta-amyloid. FEBS Lett 2005;579:4775-80. doi: 10.1016/j.febslet.2005.07.057

50. Arora A, Ha C, Park CB. Inhibition of insulin amyloid formation by small stress molecules. FEBS Lett 2004;564:1215. doi: 10.1016/S0014-5793(04)00326-6

51. Aguzzi A, Polymenidou M. Mammalian prion biology: one century of evolving concepts. Cell 2004;116:313-27. doi: 10.1016/S0092-8674(03)01031-6

52. Kanapathipillai M, Ku SH, Girigoswami K, Park CB. Small stress molecules inhibit aggregation and neurotoxicity of prion peptide 106-126. Biochem Biophys Res Commun 2008;365:808-13. doi: 10.1016/j.bbrc.2007.11.074

53. Bownik A, Stępniewska Z, Skowroński T. Protective effects of ectoine on heat-stressed Daphnia magna. J Comp Physiol. B 2014;184 961-76.

54. Bownik A, Stępniewska Z. Ectoine alleviates behavioural, physiological and biochemical changes in Daphnia magna subjected to formaldehyde. Environ Sci Pollut Res Int 2015;20:15549-62. doi: 10.1007/s11356-015-4747-5

55. Bownik A, Stępniewska Z, Skowroński T. Effects of ectoine on behavioural, physiological and biochemical parameters of Daphnia magna. Comp Biochem Physiol C Toxicol Pharmacol2015;168:2-10.doi: 10.1016/j.cbpc.2014.11.001

56. Bownik A, Stepniewska Z, Skowroński T. Protective effects of ectoine on behavioral, physiological and biochemical parameters of Daphnia magna subjected to hydrogen peroxide. Comp Biochem Physiol C Toxicol Pharmacol 2015;170:38-49. doi: 10.1016/j.cbpc.2015.02.002 


\section{Obećavajuća zaštitna svojstva ektoina u ljudi i životinja}

Ektoin je kompatibilni osmolit (osmoprotektant) koji proizvodi više bakterijskih vrsta kao odgovor na osmotski stres i nepovoljne uvjete u okolišu. Ovaj se derivat aminokiseline može nakupiti i dosegnuti visoke razine u samoj stanici a da pritom ne ometa prirodne stanične procese. Usto štiti stanicu od zračenja ili osmotskoga stresa. Svrha je ovoga članka dati kratak pregled dosadašnjih spoznaja o djelovanju ektoina u životinja, s posebnim osvrtom na praktičnu primjenu ovoga osmoprotektanta u stabilizaciji enzima, zaštiti kože u ljudi, protuupalnoga liječenja, sprječavanja ili usporavanja neurodegenerativnih bolesti te u ostalim oblicima liječenja ljudi i životinja.

KLJUČNE RIJEČI: kompatibilni osmolit; osmoprotektant; stabilnost makromolekula; zaštita stanica 